\title{
University debate boils over in Australia
}

\section{Sydney}

A radical plan by Australian education minister David Kemp to regulate the country's universities has blown up in the government's face, leaving the university system in a policy vacuum but turning its future into a highly charged political issue.

After Kemp denied in Parliament that he was contemplating major changes to policy, Labour's spokesman on education, Michael Lee, and opposition leader Kim Beazley dramatically revealed the minister's contradictions in a leaked submission to the Cabinet.

In it, Kemp disclosed: "Universities are currently in a difficult financial position ... Already, eight institutions appear to be operating at a deficit and some regional campuses are at risk."

The paper admitted that higher education "will remain a contentious issue for the government through this term [three years from October 1998]. Higher student-staff ratios, less frequent lecture and tutorial contact, ... outdated technology and gaps in the key areas of professional preparation are fuelling a perception of declining quality."

Kemp attributed this situation to "the highly regulated nature of the existing system", which he wanted to replace with a "demand-driven system". His solution was to deregulate student fees and numbers and open universities to "market forces". He wanted to give students portable vouchers, and loans at market rates, to insist on workplace reforms for staff and to gear courses and research towards commercialization.

Several senior academics had already advocated some of Kemp's proposals. Although these were bitterly opposed by staff and student bodies, all groups condemned the plan's secrecy. Lee estimated that the proposed loans scheme could take a graduate's debt to A $\$ 100,000$ (US\$64,000), and John Niland, president of the Australian Vice-Chancellors' Committee, said there were "a number of things worthy of consideration, but real rates of interest [on loans] is not one of them".

A public outcry and panic among the government's backbenchers over the threat to smaller universities triggered a hasty reversal of Kemp's plan by prime minister John Howard and his Cabinet. One plank survived, a controversial form of salary bargaining that caused a serious dispute with academic staff.

In a Green Paper on research, Kemp had revealed that he favoured reform based on restructuring rather than restoration of cuts (see Nature 400, 703; 1999). But while collecting reactions to this document, he decided that universities should be financed predominantly by students through portable vouchers, as recommended by a

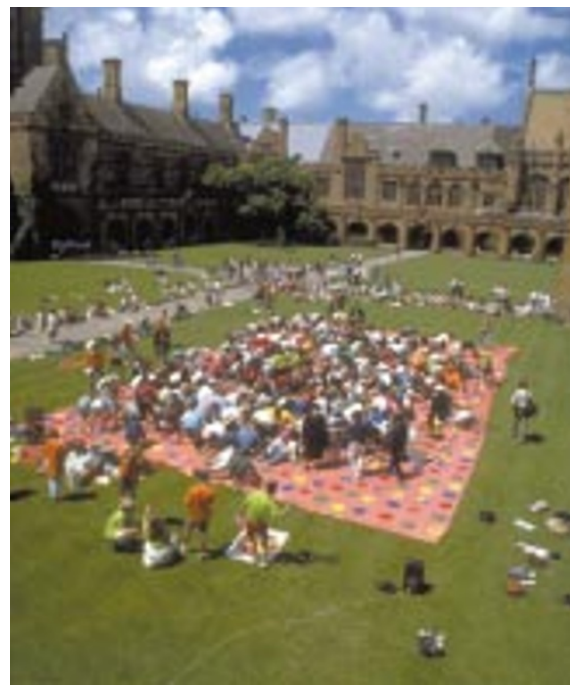

Twist and turn: the University of Sydney must try to squeeze in more students with less funding.

review of higher education by Roderick West (see Nature 392, 854; 1998). Kemp appeared to have shelved its controversial proposals before the October 1998 election.

Some leaders welcome the opportunity to push alternative policies. Gavin Brown, vice-chancellor of the University of Sydney, sees "a bright side", saying the leak brings "the urgency of the debate on higher education to the broader Australian public for the first time".

Brown favours deregulation, but believes it has been derailed by Howard's refusal to allow universities to set their own fees. He accuses Kemp of "engaging in an astonishing exercise in systematic alienation".

Brown says Australian funding is "unstable by any standards", being a sixth of that per student in the United States. He wants Australia to adopt Ireland's incentive for increasing external income through a government scheme of matching grants.

Alan Gilbert, vice-chancellor of the University of Melbourne, says "everybody is a loser". Accusing both Howard and Beazley of having "rushed to judgement, ruling out one policy option after another", Gilbert claims they "may jointly have condemned Australian higher education policy to longterm paralysis".

Mary O'Kane, vice-chancellor of the University of Adelaide, foresees a "dangerous year ahead", when the government "doesn't know what it is doing and says it has maintained funding when it has demonstrably cut it".

Peter Pockley

\section{German scientists must repay fees}

\section{Munich}

The German Administrative Court — the country's highest appeals body — has upheld a ruling that two retired medical professors from the University of Cologne must repay several million deutschmarks of fees for extra income gained from private diagnostics work.

With the agreement of both the university and the state science ministry, Gerhard Pulverer, then head of its Institute of Medical Microbiology, and Hans Eggers, then head of the Institute of Virology, had employed technical staff since the early 1970s with revenues from their private diagnostic work carried out for local hospitals and physicians in fields such as diphtheria and HIV.

In Germany, the additional income of university professors is normally subject to a fee for using state-funded equipment and staff, known as Nutzungsentgelt, of up to 50 per cent before tax. But Pulverer and Eggers had arranged with the science ministry of the Land (state) of North Rhine-Westphalia to pay only 17.5 per cent Nutzungsentgelt, in exchange for paying the salaries of additional technicians out of their own pockets.

These technicians, between 20 and 40

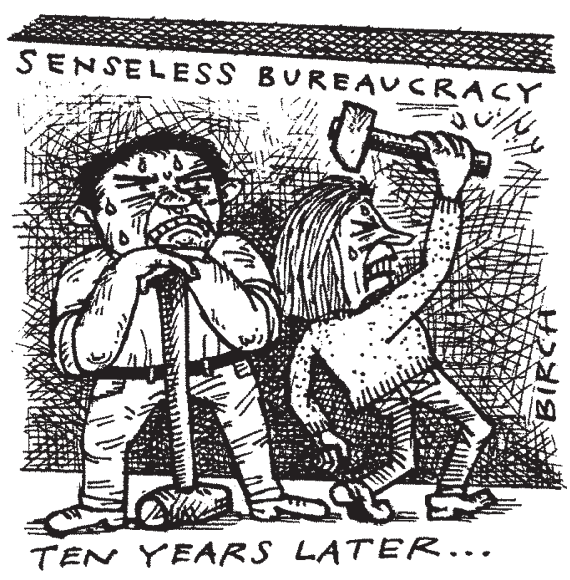

in number, carried out the laboratory work for the professors' private diagnostics. Apart from this, they were fully involved in the - previously severely understaffed — institutes' regular scientific work.

Jens Peter Meincke, the university's rector, confirms that the scheme benefited all parties, and that clinical diagnostics had gained significantly as a result.

But the court argued that the statefunded institute staff had been partly used 
for the institute heads' extra work. This, it ruled, classified the institutes as Mischbetriebe (mixed business), which, according to a 1982 decree, should have ruled out the reduction of the Nutzungsentgelt. Regular institute work and the extra occupations of technical staff, it argued, cannot be financially balanced.

Pulverer and Eggers had maintained their scheme until 1987. They claim to have received repeated verbal encouragement to do so from the university administration and ministry officials.

They now feel the victims of the unclear legal situation after 1982. Pulverer blames the ministry for its wrong advice. "The ministry's legal advisers let us walk straight into the trap," he says.

He disagrees with one judge's view that, being university professors, they should have been intelligent enough to realize they were on thin ice. "We are medics and not lawyers," he says.

Including interest, Pulverer and Eggers will be hit with bills of about DM5 and DM2.5 million [US\$2.6 and 1.3 million], respectively. "My entire savings will not be sufficient," Pulverer says, "I will also have to sell my art collection." Quirin Schiermeier

\section{Israel shuts four 'incubators' for high-tech companies}

\section{Jerusalem}

Four of Israel's 16 publicly supported 'incubators' for high-tech entrepreneurship are to close next year, says the office of Israel's chief scientist. The incubators were set up in 1991, originally to help immigrant scientists from the former Soviet Union develop their research.

Dafna Zamir, assistant to chief scientist Orna Berry, says that the closures are intended to make the programme more efficient, and that there will be no cuts in the number of projects accepted. No decision has been taken on which incubators will close, says Zamir. But the main criterion will be the number of projects that they have been able to attract.

The decision to close the incubators follows a fierce debate in the country's newspapers. Critics, including economists and some entrepreneurs, argue that the programme is a waste of money that has failed to produce profitable companies. But the programme's director, Rina Pridor, denies this and has fought successfully to preserve the current level of funding in the face of a move by treasury officials to make cuts.

The programme provides US $\$ 300,000$ in seed funds over a two-year period, as well as managerial and administrative assistance. According to the latest figures, which cover the period up to June 1999, more than half of the projects that began in the incubators have continued under their own steam after leaving the framework, most with private funds.

There has been $\$ 240$ million of private investment in incubator projects since the programme began, notes Pridor, while the government has invested $\$ 180$ million.

One of the criticisms of the programme is that some of the incubators are in outlying areas rather than big cities. This was intended to attract high-tech industry away from the crowded central region and to make the incubators available to immigrants housed in these areas during a period when Israel had to absorb more than half a million immigrants in three years. Zamir says that geography will not be a consideration in deciding which ones to close.

Elie Englender, the director of the Ofek La'Oleh incubator, located in a small town near Haifa, says he's not worried, because he has no shortage of projects. He says the current grants make it difficult for incubator start-up companies to pay their researchers decent salaries.

Haim Watzman

\section{\$2m ransom sought for kidnapped ecologists}

\section{Moscow}

The Polish government last week rejected demands from Chechen kidnappers for $\$ 1$ million each for the release of two Polish scientists taken captive in August in Dagestan, one of the Russian North Caucasian republics bordering Chechnia.

Zofia Fiszer-Malanowska of the Warsaw Ecology Institute of the Polish Academy of Sciences, and Ewa Marchwinska-Wyrwal of the Ecology Institute of Katowice, had travelled to Dagestan at the invitation of Rasul Magomedov of the Biological Resources Institute of the Russian Academy of Sciences in Makhachkala, the capital of Dagestan.

The two ecologists arrived at the beginning of August and stayed at Magomedov's house. Soon all of them, together with Aleksander Karamasov, another Dagestanian scientist, moved to the Gunib region for ecological research. After the expedition failed to return at the expected time, the police started an investigation, but found only the car the scientists had used.

In September, relatives of Magomedov managed to negotiate his release. But his colleagues were left in captivity. A handwritten

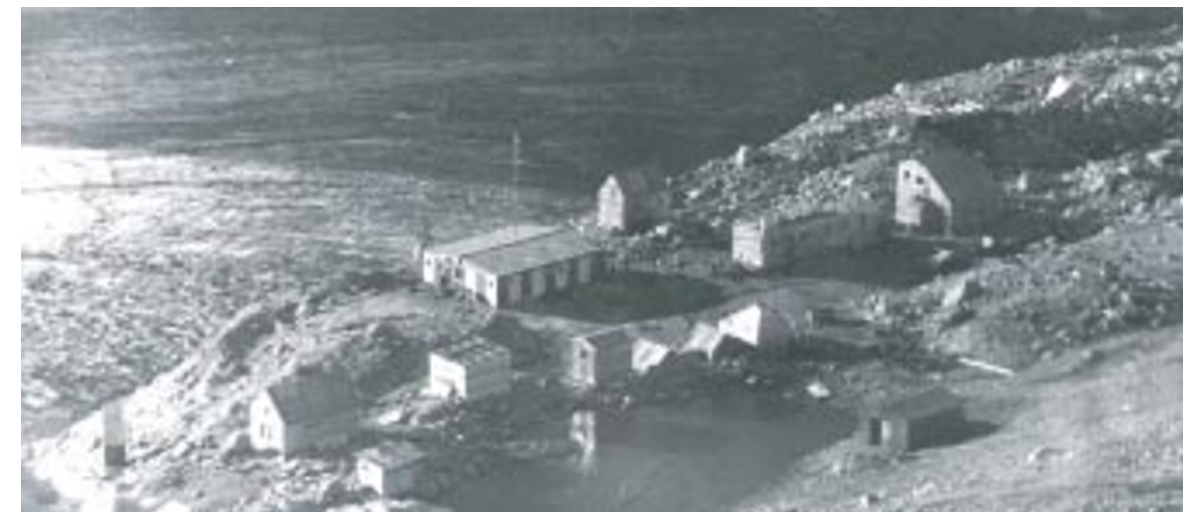

Danger zone: this science base on the Abramov glacier, at 4,000-metres altitude in the Pamir mountains of Kyrgyzstan, was burned by terrorists in September. The base was set up in the former Soviet republic by the Central Asia Hydrometeorological Institute more than $\mathbf{3 0}$ years ago.

note from the hostages was planted on the Polish embassy in Moscow last week. In the note, the hostages ask for help because of their deteriorating health (both women are approaching 60). They are being held in a concrete cellar in Urus-Martan, Chechnia.

"We have no other information about our two citizens except that both are alive," says a spokesman for the embassy. The Polish authorities declared that they will not pay the ransom. A Polish diplomat plans to visit Georgia in a bid to negotiate for the release of the women.

Kidnapping appears to have become an increasing hazard for researchers working in the former Soviet Union, where the activity has become an important source of income for dissident groups.

Carl Levitin 